\title{
Evaluation of catch-and-release angling practices for the fat snook Centropomus parallelus in a Brazilian estuary
}

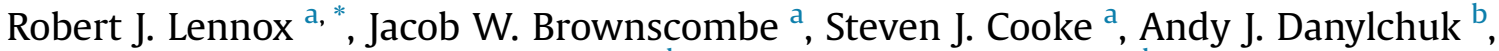 \\ Pietro S. Moro ${ }^{\mathrm{c}}$, Eduardo A. Sanches ${ }^{\mathrm{d}}$, Domingos Garrone-Neto ${ }^{\mathrm{d}}$ \\ ${ }^{a}$ Fish Ecology and Conservation Physiology Laboratory, Department of Biology, Carleton University, Ottawa, ON K1S 5B6, Canada \\ ${ }^{\mathrm{b}}$ Department of Environmental Conservation, University of Massachusetts Amherst, Amherst, MA, USA \\ ${ }^{\mathrm{c}}$ Moro Fishing Ltd., R. José Benedito Cotolengo 819, Curitiba, PR 81220-310, Brazil \\ d UNESP - São Paulo State University, College of Fishery Engineering, Av. Nelson Brihi Badur 430, Registro, SP 11900-000, Brazil
}

\section{A R T I C L E I N F O}

\section{Article history:}

Received 3 December 2014

Received in revised form

27 April 2015

Accepted 6 May 2015

Available online 16 May 2015

\section{Keywords:}

Recreational fisheries

Tournament angling

Stress physiology

Reflex action mortality predictors

Centropomidae

\begin{abstract}
A B S T R A C T
Recreational fisheries are developing for many iconic marine and estuarine fish species and are generating important social and economic returns in Brazil. Fat snook is the primary target species in southeastern Brazil and it supports a vibrant fisheries sector, including recreational fishing tournaments. To evaluate the impacts of recreational angling practices, we examined external hooking injuries, secondary physiological stress responses (i.e., blood glucose and lactate concentrations; $\mathrm{N}=24$ ), reflex impairment $(\mathrm{N}=39)$, and overnight survival $(\mathrm{N}=39)$ of fat snook angled with and without air exposure. We also examined physiological stress and reflex impairment of fat snook captured in a fishing tournament $(\mathrm{N}=43)$ immediately post weigh-in and $1 \mathrm{~h}$ post weigh-in. Values were compared to baseline reflexes $(\mathrm{N}=10)$ and physiology $(\mathrm{N}=8)$ collected from minimally stressed fat snook. Fish captured by anglers infrequently had hooking injury but all angling and tournament treatments resulted in significantly elevated blood glucose and lactate, indicating a considerable physiological response to angling. Angling with air exposure and tournament weigh-in (in a dry container) resulted in the highest blood lactate values. The body flex reflex was occasionally impaired after angling or tournament practices, but this was consistent with baseline reflex actions, and the body flex reflex was therefore not a valuable indicator of fisheries stress or mortality in fat snook. Although angling and tournament practices caused a marked physiological stress response, low mortality of snook indicated that the species is resilient to brief bouts of angling at moderate water temperatures. However, high lactate values associated with air exposure suggest that handling practices be refined, particularly during tournament weigh-in. We recommend that anglers reduce air exposure intervals when handling snook prior to release and that recreational tournaments adopt wet weigh-in procedures to maximize the utility of catch-and-release in this fishery.
\end{abstract}

(c) 2015 Elsevier Ltd. All rights reserved.

\section{Introduction}

Fishing represents a significant component of estuarine and coastal ecosystem use, employment, and nutrition for many communities (Dyck and Sumaila, 2010). However, a high degree of human interaction with these areas has resulted in degradation of many coastal and estuarine ecosystems (Lotze et al., 2006). Artisanal fisheries, in which fishers capture fish primarily for household subsistence but may sell surplus (Harden Jones, 1994; Rawlinson et al., 1995), are vital to food security and relatively important

\footnotetext{
* Corresponding author.

E-mail address: robert.lennox@carleton.ca (R.J. Lennox).
}

sources of employment to people in these regions (FAO, 2000). In Brazil, many traditional estuarine fishing communities are faced with external pressures advocating resource conservation, which may conflict with local interests that tend towards resource exploitation for subsistence (Hanazaki et al., 2007).

Artisanal fishing (using cast nets or bamboo weirs) has long been an important activity for communities throughout the Iguape and Cananéia Lagoon-Estuarine Complex, Southeastern Brazil (Mourão, 1971), intensifying in the 1960s as a result of improved fishing technologies (Diegues, 1983). Since at least the 1970s, artisanal fisheries have co-occurred with recreational fisheries in the region (Hanazaki et al., 2007) and a transition is now ongoing 
within the estuary from traditional artisanal fisheries towards recreational fisheries becoming the dominant sector (Barcellini et al., 2013). In southeastern Brazil, a primary target of both artisanal and recreational fisheries is fat snook (Centropomus parallelus). Fat snook is preferred for its eating quality (Lemos et al., 2006), but the species is considered to be overfished in the Iguape and Cananéia Lagoon-Estuarine Complex (Moro, 2008; Moro et al., 2010). Recently, an increasing proportion of the recreational catch has been released by anglers (i.e., catch-and-release; $C \& R)$, especially in association with local fishing tournaments that are growing in popularity among recreational anglers - a pattern considered to be consistent throughout Brazil (Freire et al., 2012). Recreational fisheries can equally affect fish stocks (Post et al., 2002), however, the extent to which fish that are released end up dead or experiencing sublethal consequences as a result of catch-and-release fishing is unknown for nearly all Brazilian fish species. Without biological assessment, it is difficult to evaluate the sustainability of recreational fisheries or to identify and promote best-handling practices.

A variety of approaches can be useful for evaluating the consequences of fishery interaction with fish, including assessments of injuries (Muoneke and Childress, 1994), physiological disturbance (Cooke et al., 2013), reflex impairment (Davis, 2010), and mortality (e.g., Taylor et al., 2001). Recording anatomical hooking locations and characterizing external injuries such as tissue damage or bleeding can provide useful metrics for identifying potential issues related to fishing gear (i.e., how factors such as hook size, hook configuration, angler experience influence injury outcomes). Because deep hooking and bleeding are considered strong predictors of mortality in recreational fisheries (Bartholomew and Bohnsack, 2005), they are logical endpoints to examine in $C \& R$ studies. In conjunction with visually quantifying injuries related to angling, measurements of circulating metabolites associated with the secondary stress response can index the internal disturbance experienced by fish as a result of angling activities (Cooke et al., 2013; Wedemeyer and Wydoski, 2008). Acute stress associated with angling can have latent tertiary consequences, such as altering immunological status (Barton, 2002), inhibiting growth, and altering behavior due to locomotory and cognitive impairment (e.g., Brownscombe et al., 2013, 2014; Cooke et al., 2000), which can in turn increase the risk of predation (e.g., Danylchuk et al., 2007; Raby et al., 2014). Measuring reflex action mortality predictors (RAMP; Davis, 2005, 2007) can provide an assessment of locomotory or cognitive impairment by testing reflex actions that are related to the autonomic nervous system and motoneural responsiveness of fish (Davis, 2005, 2010; Raby et al., 2012). Theoretically, the RAMP index can provide information about the stress status of a fish rapidly and efficiently, and in practice it has been used to predict ecologically-relevant endpoints such as mortality (Davis, 2010) and migration failure (Raby et al., 2012) of various species. However, species-specific evaluations are necessary to validate RAMP and determine how reflex impairment, physiological disruption, and hooking injuries correspond to mortality of fish that are released. Holding fish in pens, cages, or tanks (e.g., Taylor et al., 2001) is a fundamental aspect of $C \& R$ science because it enables the estimation of $C \& R$ mortality extending from injury or sublethal physiological impairment. When these techniques are combined, it is possible to obtain a comprehensive understanding of $C \& R$ practices for a fishery that is useful for a variety of stakeholders.

Although C\&R science is well established, nearly all of the literature is focused on popular gamefish in North America, Europe, and Australia (Arlinghaus et al., 2007). Given that there is immense interspecific variation in responses of fish to $C \& R$ (Cooke and Suski, 2005), it is difficult to make generalizations about the effects of $C \& R$ from other species or regions to species such as fat snook in Brazil. There are two $C \& R$ studies on a congeneric snook species (i.e., Centropomus undecimalis) from Florida (Lowerre-Barbieri et al., 2003; Taylor et al., 2001), but they were relatively specialized studies that would not be applicable to fat snook fisheries in Brazil. Moreover, they did not consider fishing in the context of recreational fishing tournaments, which have components that can be stressful for fish independent of typical angling (Schramm et al., 1991; Suski et al., 2004). In the Iguape and Cananéia Lagoon-Estuarine Complex (LEC) in Brazil, we undertook an integrated study to evaluate the injury, sublethal physiological alterations, reflex impairments, and short-term mortality arising from fat snook $C \& R$ angling. Given the growing importance of fishing tournaments in this region, we also evaluated the status of fat snook after various stages of the tournament process.

\section{Methods}

\subsection{Study area}

Fat snook were collected via angling in the Iguape and Cananéia Lagoon-Estuarine Complex (LEC), which is a biodiversity hotspot in Southeastern Brazil (Barella et al., 2014). The LEC is remnant drainage of the Atlantic Forest ecosystem, which is an ecologically important biome with a high degree of endemism that has become greatly diminished as a result of human disturbance (Barcellini et al., 2013; Barella et al., 2014). Due to its relatively pristine nature and to the presence of traditional communities (Contente et al., 2011; Lana et al., 2001), the area has been designated as a UNESCO Natural World Heritage Site (Barcellini et al., 2013) and most is legally protected (Lino and Moraes, 2005).

\subsection{Angling experiments}

The first component of the experiment involved collection of fat snook by seven anglers in two boats via angling in Ariri, Cananéia City, São Paulo State, Southeastern Brazil $\left(25^{\circ} 13^{\prime} 06^{\prime \prime}\right.$ S, $48^{\circ} 02^{\prime} 24^{\prime \prime}$ W). Samples were collected on September 9 and 10, 2014 at water temperature of $22{ }^{\circ} \mathrm{C}$. Fat snook samples were captured by angling using conventional medium-strength spinning rods with $8 \mathrm{~kg}$ break strength braided Dacron fishing line with a $1 \mathrm{~m}$ fluorocarbon leader and either live shrimp on a size $1 / 0$ wide-gap J-hook or artificial baits on weighted jig head J-hooks (without support hooks). Fish were landed using a knotted monofilament landing net (not the ideal landing vessel [rubberized net], but what local anglers use in this region) and the duration of the fight was timed. When landed, fish were immediately transferred to a livewell with continuously recirculating water, hooking location was recorded, and hooking injuries were assessed (i.e., presence of blood, other tissue damage). Critical hooking locations included deeply lodged hooks (i.e., in the esophagus or gullet), hooks lodged in the gills, hooks penetrating the eye (e.g., Siewert and Cave, 1990), or hooks piercing the body outside the jaw (i.e., foul hooking). Once individuals were removed from the hook, the total length was measured, an external t-bar anchor tag (Floy Tag and Mfg. Inc., Washington, USA) was affixed in the dorsal musculature for identification, and the individual was assigned to either the air exposure or no air exposure handling treatment. The no air exposure group underwent a rapid RAMP assessment (Davis, 2005, 2010) while submerged in water in the livewell. Fish assigned to the air exposure group were removed from the livewell for an air exposure treatment of $1 \mathrm{~min}$ prior to RAMP assessment. To quantify baseline physiological values, an additional group of snook was rapidly 
retrieved by anglers ( $<5 \mathrm{~s}$ ) and blood sampled immediately upon landing (i.e., within 3 min of initial hooking; Pankhurst, 2011).

After one hour in a livewell (water circulated and aerated), fat snook were transferred to a water-filled plastic trough for drawing of $0.75 \mathrm{~mL}$ of blood via caudal venipuncture using a $18 \mathrm{~g}$ syringe and a $3 \mathrm{~mL}$ heparinized Vacutainer ${ }^{\circledR}$. Blood was analyzed onsite using point-of-care devices calibrated for use with fish (Stoot et al., 2014) for blood-plasma lactate (mmol/L, Lactate Pro LT-1710, Akray Inc., Kyoto, Japan) and glucose (mmol/L, Accu-Chek Compact Plus, Roche Diagnostics, Basel, Switzerland). The five RAMP indicators were assessed to quantify impairment associated with anglingrelated activities: tail grab response, equilibrium, body flex, vestibular ocular response (VOR), and head complex, which were developed for rapid and accessible evaluation of fish condition (e.g., Davis, 2005; Raby et al., 2012; Brownscombe et al., 2013). Although we could use short bouts of angling to generate baseline physiological measurements (Pankhurst, 2011), even such short bouts of angling could be expected to impair reflexes of snook therefore to generate baseline reflex data we subsampled 10 snook that were held for $18 \mathrm{~h}$ monitoring for reflexes before releasing them. Given the low densities at which they were held and the period for which they allowed recovered, we reasoned that these fish would provide a reasonable estimate of baseline RAMP scores.

To quantify mortality from angling, a subset of fish from the angling experiments was held in a $500 \mathrm{~L}$ plastic tank $\left(22^{\circ} \mathrm{C}\right)$ with flow through ambient estuarine water to monitor for mortality. The fish were held overnight and released the following morning $(18 \mathrm{~h})$. The tank was checked throughout the day and the following morning for mortalities. Any individuals that died were to be removed immediately and individually identified from the external tag. Surviving fish were released at the end of the holding period.

\subsection{Tournament sampling}

To determine how tournament practices affected fat snook, we collaborated with a local amateur fishing tournament at Porto Cubatão in Cananéia City, São Paulo State, Southeastern Brazil $\left(24^{\circ} 58^{\prime} 42^{\prime \prime}\right.$ S, $\left.47^{\circ} 56^{\prime} 50^{\prime \prime} \mathrm{W}\right)$ on September 6, 2014. Forty boats participated in the tournament and all fish were eligible for weigh, but snook species ( $C$. undecimalis and $C$. parallelus) were required to be weighed alive. Snook were returned to the weigh-in station having been held for up to eight hours in livewells during the day. At the weigh-in station, fat snook were individually transferred from the boats to a dry plastic container for official weighing. After the weighing procedure, we intercepted fat snook for measurement, external tagging with t-bar anchor tags (Floy Tag and Mfg. Inc., Washington, USA), and divided the sample into two treatment groups for the experiment. The first treatment group was immediately tested for reflex impairment (i.e., RAMP), blood sampled, and then released. The second group was transferred to one of two $500 \mathrm{~L}$ plastic tanks with continuously recirculating water $\left(22^{\circ} \mathrm{C}\right)$. After one hour, these fat snook were blood sampled and released. Blood sampling and RAMP procedures were identical to those used for the angling experiments (see above). Data about fight duration, air exposure duration, holding period in the livewell, and hooking location were not available.

\subsection{Data analysis}

Low rates of hooking injury and bleeding precluded statistical analysis and descriptive statistics are presented as an alternative where appropriate. Physiological measurements were compared among baseline, angling, and tournament treatments using linear mixed effects models with the package nlme in $\mathrm{R}$ ( $\mathrm{R}$ Core Team,
2014). Treatment was a fixed effect and fish size, split into a binary categorical factor based on empirical size at maturity (230 mm; Alvarez-Lajonchère and Tsuzuki, 2008), was incorporated as a random effect to account for potential differences among sizes. To correct patterns in the residuals, glucose and lactate values were log transformed. To make multiple comparisons among treatments, subsequent inferences were made using the multcomp package in R, which performed Tukey-Kramer HSD tests. RAMP scores (Davis, 2007; Raby et al., 2012) were compared among treatments using a one-way analysis of variance (ANOVA). A likelihood ratio G-test was used to compare 18 h survival between the two groups. Student's two-tailed t-tests were used to compare glucose and lactate values with reflex impairment (i.e., not impaired compared to impaired; a score of 0.0 compared to a score of 0.2 ). Although results from the angling experiment and the tournament experiment are presented separately, statistical tests included all treatments from angling and tournament experiments as well as baseline values. All data are presented as mean \pm SD and the level of significance for statistical tests was $\mathrm{p} \leq 0.05$.

\section{Results}

\subsection{Angling experiment}

During the two day angling experiment, 47 fat snook $(271 \pm 87 \mathrm{~mm} \mathrm{TL})$ were captured, 42 of which were captured by lures and nine on shrimp suspended under a bobber. All individuals were retrieved relatively rapidly ( $11 \pm 8 \mathrm{~s}$; range $2-30 \mathrm{~s}$ ). Most fish were hooked superficially in the jaw but three, $8 \%$, were hooked in critical locations. One of the fat snook was foul hooked along the ventral side, one was hooked in the esophagus and categorized as deeply hooked, and one was hooked at the base of the eye. Only the foul hooked fat snook had a visible hooking injury and no fat snook bled at hook locations.

Eight fat snook were blood sampled immediately upon capture to establish baseline values, 19 were assigned to the $0 \mathrm{~s}$ air exposure treatment group, and 20 were assigned to the $60 \mathrm{~s}$ air exposure treatment group. Blood samples were drawn from 12 individuals in each treatment group (Table 1 ), the remainder were not blood sampled but were assigned to the holding study to calculate shortterm survival (results below). Relative to baseline, angling with either $0 \mathrm{~s}$ or $60 \mathrm{~s}$ air exposure resulted in increased plasma glucose and lactate values (Table 2). Although average blood glucose and lactate were higher for fish that experienced air exposure in addition to angling, neither difference was significant (Figs. 1 and 2).

No individuals exhibited impairment of the tail grab, equilibrium, head complex, or of the vestibular ocular response reflexes. Only the body flex reflex was impaired and therefore RAMP score was either 0.0 (no impairment) or 0.2 (one reflex impaired). However, among the 10 fat snook that we subsampled at the end of the $18 \mathrm{~h}$ holding period to determine baseline RAMP scores, four exhibited impaired body flex. RAMP scores were not different across treatments or relative to baseline $\left(F_{3,51}=0.10 \mathrm{p}=0.96\right)$.

After angling, 39 fat snook were held for $18 \mathrm{~h}$ to calculate mortality, 24 of which were also blood sampled and 15 of which were not blood sampled (Table 1). Only one fat snook (from the $0 \mathrm{~s}$ air exposure treatment) was confirmed dead from angling, which occurred approximately one and a half hours after hooking and before transfer from the livewell to the holding tank. The individual had been foul hooked along the ventral side, which resulted in a wound that visibly damaged internal organs. Therefore, within $18 \mathrm{~h}$ of angling, 97\% of fat snook survived. Survival did not differ between the $0 \mathrm{~s}$ and $60 \mathrm{~s}$ air exposure treatment group $\left(\mathrm{G}_{1}=1.47\right.$, $\mathrm{p}=0.23$ ). 
Table 1

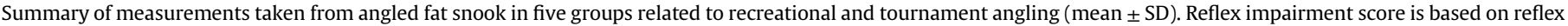

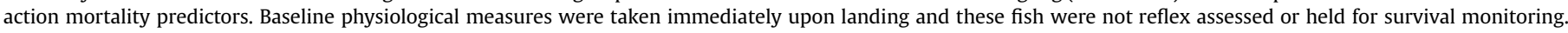

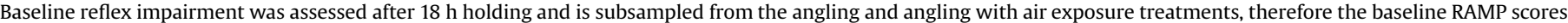

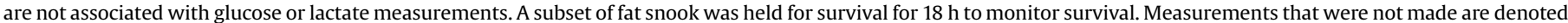
by $\mathrm{n} / \mathrm{a}$.

\begin{tabular}{|c|c|c|c|c|c|c|c|c|}
\hline Treatment & RAMP N & Physiology N & Survival N & Survival & Length (mm) & Glucose $(\mathrm{mmol} / \mathrm{L})$ & Lactate $(\mathrm{mmol} / \mathrm{L})$ & RAMP score \\
\hline Baseline & 10 & $\mathrm{n} / \mathrm{a}$ & $\mathrm{n} / \mathrm{a}$ & $\mathrm{n} / \mathrm{a}$ & $\mathrm{n} / \mathrm{a}$ & $\mathrm{n} / \mathrm{a}$ & $\mathrm{n} / \mathrm{a}$ & $0.08 \pm 0.1$ \\
\hline Baseline & $\mathrm{n} / \mathrm{a}$ & 8 & 0 & $\mathrm{n} / \mathrm{a}$ & $277 \pm 26$ & $2.7 \pm 2.2$ & $1.6 \pm 0.9$ & $\mathrm{n} / \mathrm{a}$ \\
\hline Angling & 19 & 12 & 19 & $95 \%$ & $282 \pm 17$ & $10.4 \pm 1.8$ & $6.3 \pm 0.7$ & $0.06 \pm 0.1$ \\
\hline Angling and air & 20 & 12 & 20 & $100 \%$ & $278 \pm 16$ & $13.7 \pm 1.8$ & $8.1 \pm 0.7$ & $0.08 \pm 0.1$ \\
\hline Post weigh-in & 21 & 21 & 0 & $\mathrm{n} / \mathrm{a}$ & $310 \pm 16$ & $10.9 \pm 1.4$ & $7.3 \pm 0.6$ & $0.09 \pm 0.1$ \\
\hline $1 \mathrm{~h}$ post weigh-in & 22 & 22 & 0 & $\mathrm{n} / \mathrm{a}$ & $354 \pm 16$ & $16.6 \pm 1.4$ & $9.7 \pm 0.5$ & $\mathrm{n} / \mathrm{a}$ \\
\hline
\end{tabular}

Table 2

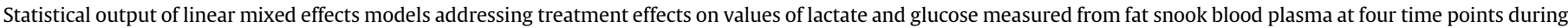

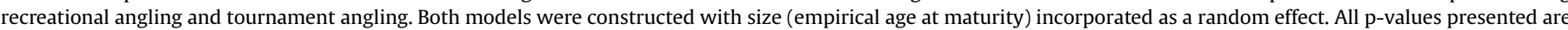

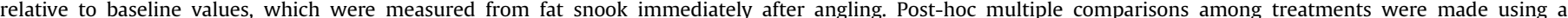
Tukey-Kramer HSD test, the results of which are presented in Figs. 1 and 2.

\begin{tabular}{|c|c|c|c|c|c|c|}
\hline Variable & Parameter & Estimate & S.E. & DF & t-value & p-value \\
\hline \multirow[t]{5}{*}{ Log (Lactate) } & (Intercept) & 0.34 & 0.14 & 68 & 2.40 & 0.02 \\
\hline & Angling $0 \mathrm{~s}$ air exposure & 1.40 & 0.18 & 2 & 7.76 & 0.02 \\
\hline & Angling $60 \mathrm{~s}$ air exposure & 1.64 & 0.18 & 68 & 8.92 & $<0.01$ \\
\hline & Post weigh-in & 1.56 & 0.17 & 2 & 9.35 & 0.01 \\
\hline & $1 \mathrm{~h}$ post weigh-in & 1.93 & 0.17 & 2 & 11.57 & 0.01 \\
\hline \multirow[t]{5}{*}{ Log (Glucose) } & (Intercept) & 0.76 & 0.36 & 69 & 2.12 & 0.04 \\
\hline & Angling $0 \mathrm{~s}$ air exposure & 1.28 & 0.26 & 69 & 4.95 & $<0.01$ \\
\hline & Angling $60 \mathrm{~s}$ air exposure & 1.67 & 0.27 & 69 & 6.22 & $<0.01$ \\
\hline & Post weigh-in & 1.26 & 0.24 & 69 & 5.34 & $<0.01$ \\
\hline & $1 \mathrm{~h}$ post weigh-in & 1.65 & 0.24 & 69 & 7.03 & $<0.01$ \\
\hline
\end{tabular}

\subsection{Tournament experiment}

During the amateur tournament, 81 snook were returned to the weigh-in station by anglers, 77 fat snook and four common snook. All snook received individual t-bar tags but only 43 $(332 \pm 77 \mathrm{~mm} \mathrm{TL})$ were assigned to the two treatment groups, for which blood samples were taken either immediately post weigh-in or $1 \mathrm{~h}$ post weigh-in (Table 1 ).

Fat snook from both tournament treatment groups had significantly elevated lactate and glucose values relative to baseline (which were collected during angling trials, see above; Table 2;

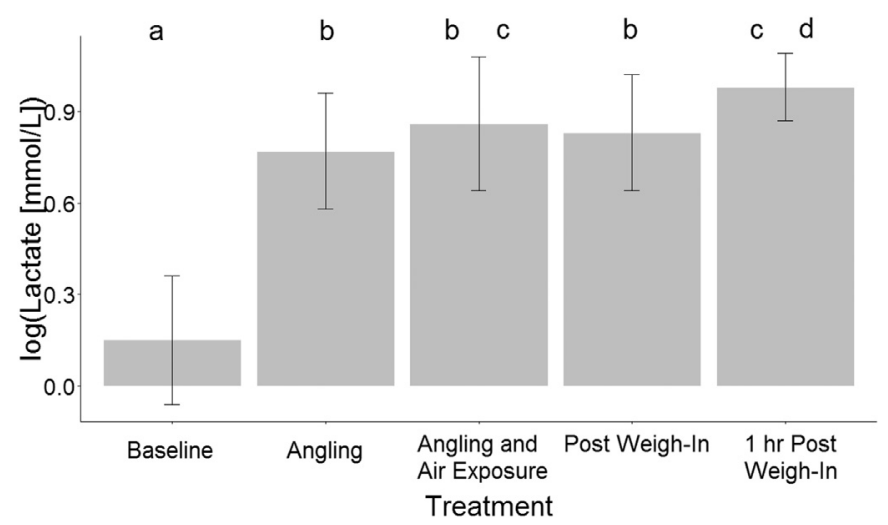

Fig. 1. Mean log transformed blood lactate concentrations of fat snook. Livewell holding and weigh-in values are from a local amateur tournament whereas all other values are from independent angling trials. Different letters indicate significant differences between treatments based on Tukey-Kramer HSD multiple comparisons of a linear mixed effects model constructed to evaluate the effect of different angling activities. Error bars indicate one standard deviation around the mean.
Figs. 1 and 2). Lactate values $1 \mathrm{~h}$ post weigh-in were significantly higher than values measured immediately after weigh-in (Fig. 2). Although glucose followed a similar trend, the difference was not significant (Fig. 1). Lactate values $1 \mathrm{~h}$ post weigh-in were significantly higher than lactate values among fat snook that experienced angling and $0 \mathrm{~s}$ air exposure, but not different from values recorded for fat snook that experienced angling and $60 \mathrm{~s}$ air exposure.

As with the angling experiments, only the body flex reflex became impaired after weigh-in. Thus, no fat snook responded to the weigh-in procedure with significant reflex impairment and RAMP scores were either 0.0 or 0.2 . Overall, only nine fish exhibited any reflex impairment. RAMP scores associated with the weigh-in

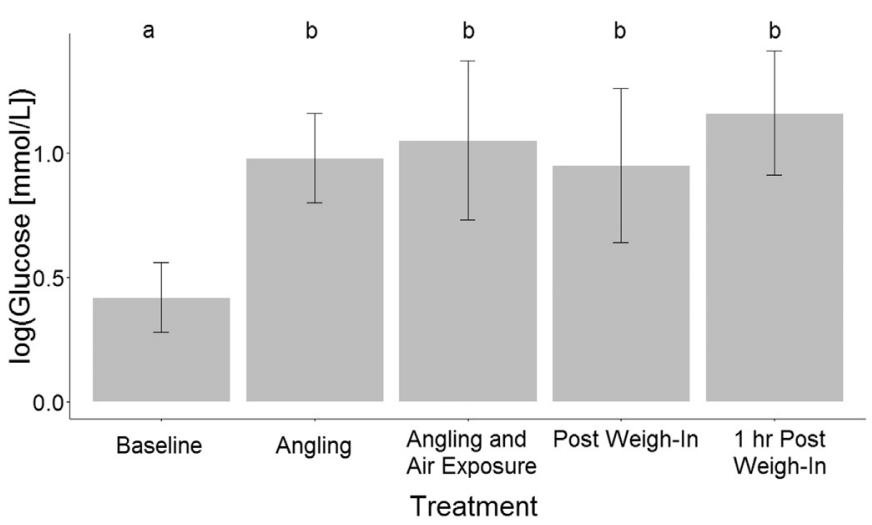

Fig. 2. Mean log transformed blood glucose concentrations of fat snook. Livewell holding and weigh-in values are from a local amateur tournament whereas all other values are from independent angling trials. Different letters indicate significant differences between treatments based on Tukey-Kramer HSD multiple comparisons of a linear mixed effects model constructed to evaluate the effect of different angling activities. Error bars indicate one standard deviation around the mean. 
were not different from baseline RAMP scores or RAMP scores associated with the angling experiment $\left(F_{3,51}=0.10 \mathrm{p}=0.96\right)$. In addition, reflex impairment did not relate to concentrations of lactate $(\mathrm{t}=-1.15, \mathrm{p}=0.25)$ or concentrations of glucose $(\mathrm{t}=-0.97$, $\mathrm{p}=0.33)$.

\section{Discussion}

Recreational fisheries provide economic stimuli that benefit local communities and can be relatively effective conservation measures for fish species (Arlinghaus and Cooke, 2009; Cooke and Schramm, 2007). In Brazil, the recreational sector represents an increasingly important segment of fisheries and tournament angling with live release components is becoming a popular activity among locals. However, recreational fisheries and fishing tournaments can be stressful for fish (reviewed in Cooke and Suski, 2005), meaning that releasing fish may have unintended fitness consequences. In this study, we have used a variety of ecologically relevant metrics to quantify the impacts of angling activities such as playing, air exposing, retaining, weighing, and releasing fat snook. These results are timely because the species is a popular target of Brazilian marine, riverine, and estuarine fisheries. Surprisingly, there are limited data available for assessing the suitability of $C \& R$ angling for maintaining populations of this important predator.

Injury of fat snook was very infrequent in this study, and even though some fish were captured using passive fishing with bobbers and live bait, incidents of deep hooking and injury were nonetheless rare. In other studies, live bait fishing, particularly passively such as with bobbers, has been shown to result in high rates of deep hooking (Alós, 2009; Lennox et al., 2015). The low injury rates among fat snook were probably attributable to the use of large (relative to the size of the fish) wide gap hooks, which precluded swallowing by most of the fat snook captured. Alós et al. (2008) demonstrated conservation benefits of large hooks for derbio (Trachynotus ovatus), indicating that the use of relatively large hooks for fat snook fishing may have contributed to relatively low rates of injury and mortality (see also Wilde et al., 2003). Cooke et al. (2013) also found that the use of wide gap hooks resulted in no deep hooking or bleeding in rock bass (Ambloplites rupestris), and this relatively new hook type could be an effective tool for C\&R fishing. However, few studies have considered the hooking tendencies (i.e., deep vs shallow hooking) of wide gap hooks.

Angling durations were typically short in this study, meaning that the degree of anaerobiosis associated with burst exercise was likely minimal for most fat snook (Dobson and Hochachka, 1987; Kieffer, 2000; Milligan and Wood, 1986). Nonetheless, fat snook exhibited significant measures of stress and exhaustion associated with angling activities. Indeed, some snook had glucose concentrations that were exceptionally high $(>20 \mathrm{mmol} / \mathrm{L})$, although on average the values were similar to those published for other recreationally important species (e.g., common carp [Cyprinus carpio] Pottinger, 1998; bonefish [Albula vulpes] Suski et al., 2007). Lactate values also became significantly elevated, particularly for fat snook that underwent weigh-in at the amateur tournament. The weigh-in procedure was conducted in air rather than in water-filled bags (e.g., Suski et al., 2004), resulting in air exposure as the fish were observed struggling to escape with vigorous muscle contractions indicative of anaerobic exercise. When held in air, fish respire anaerobically and recruit white muscular contractions for movement, which produces lactate and a free metabolic proton from the metabolism of glycogen (Milligan and Wood, 1986; Wood et al., 1983; Wood, 1991). Re-synthesis of lactate to glycogen after exercise is energetically expensive and can delay activity in fish (Wood, 1991). Air exposure also activates the hypothalamus-pituitaryinterrenal axis, resulting in increased epinephrine, norepinephrine, cortisol, and the mobilization of glucose from the liver into the bloodstream (Barton, 2002; Mazeaud et al., 1977; Mommsen et al., 1999; Wendelaar Bonga, 1997). Previous studies have implicated air exposure after angling as a factor that can increase stress and metabolic exhaustion (e.g., Thompson et al., 2008), prolong recovery time (e.g., White et al., 2008), and reduce survival (e.g., Ferguson and Tufts, 1992) of fish. Hyperglycemia is a secondary consequence of stress in fish (Barton, 2002) and can be taken as a measurement of the generalized stress response in fish to study the effects of stressful or energetically costly encounters such as angling (Wedemeyer and Wydoski, 2008). Increased glucose is mediated immediately by catecholamines whereas cortisol contributes to sustained elevation (Thomas, 1990). In this study, lactate and glucose values were highest for fat snook that were angled and air exposed and for those that underwent weigh-in, both being treatments where the fish experienced air exposure of approximately $1 \mathrm{~min}$. In general, recovery from air exposure is affected by a variety of factors, particularly water temperature (e.g., Gingerich et al., 2007), although this variable was relatively constant during this study and near normal seasonal temperatures in the estuary (Barella et al., 2014).

Although there was a measurable physiological response to angling, changes did not manifest in reflex impairment, with most snook having low RAMP scores. Progressively higher RAMP scores indicate increasing degrees of muscular exhaustion and cognitive impairment (Raby et al., 2012), and high RAMP scores have been related to mortality of some species (Davis, 2005; Davis and Ottmar, 2006; Humborstad et al., 2009). In this study, fat snook were only observed losing the body flex reflex. According to Raby et al. (2012), body flex is typically impaired because of muscular exhaustion rather than motoneural impairment; however, given that the loss of body flex was consistent across treatments, including the baseline treatment, and not related to the magnitude of physiological disturbance or mortality, this reflex action may have little value as an index of impairment for the species. van Raaij et al. (1996) have shown that coping strategy of fish handled and exposed to air is an important determinant of survival. Rainbow trout (Oncorhynchus mykiss) that struggled when handled quickly reached the anaerobic threshold, exhibited high cortisol, and died more frequently than individuals that remained calm (van Raaij et al., 1996). Given the unpredictability inherent in estuarine environments, reduced activity under stress may be adaptive to reduce aerobic debt among this estuarine fish, manifesting in our study as low body flex during handling.

Ultimately, low mortality of fat snook after short-term holding provided evidence that this species may be relatively resilient to both angling and air exposure of relatively short durations and moderate water temperatures tested here. This result aligns with the findings of Taylor et al. (2001), who calculated low (2\%) 48$\mathrm{h}$ mortality of congeneric common snook after angling. High survival from angling and air exposure is promising and indicates that, given good handling practices, fat snook immediately released back into the wild would also have high survival. However, there are other challenges for stressed fish when released into the wild that cannot be measured with holding studies. After release, stress, exhaustion, and cognitive impairment can contribute to locomotor impairment and impaired refuge-seeking (Brownscombe et al., 2013, 2014; Cooke et al., 2014; Danylchuk et al., 2007). Cognitive and behavioral impairment can increase the likelihood of postrelease predation (Raby et al., 2014). Fish released from tournaments may be at particular risk, because it was noted that fat snook were released from a common meeting point far removed from mangrove habitats where snook generally seek cover. It may take snook some time to travel across the estuary back to typical cover habitat, especially given that we found the weigh-in procedure to 
provoke a strong physiological stress response. Studies of black bass (Micropterus spp.) released from tournaments have indicated that some do not successfully return to capture sites (Bunt et al., 2002; Wilde, 2003), meaning that returning fish to capture sites prior to release may be an important consideration for live release angling tournaments.

We were afforded the opportunity to collaborate closely with local anglers and tournament organizers interested in the conservation of the species, which permitted observations of typical angler behavior and angling practices in the region. Although interest in snook conservation appeared to be high, it was noted that few individuals were apprised of best angling practices, even among relatively conservation-oriented fishers. For instance, fish were often landed with knotted monofilament landing nets (which increase abrasion and exacerbate stress; Barthel et al., 2003), held out of water for extended periods, and weighed at the tournament in a dry container. Angler education and dissemination of information about best practices for fish handling are crucial for changing angling norms and improving the condition of fish that are released by anglers in fisheries (Pelletier et al., 2007). Simple changes such as weighing fish while submerged in water (e.g., Suski et al., 2004) would probably have reduced physiological stress that was associated with the weigh-in at the amateur tournament.

\section{Conclusion}

Although human settlement and exploitation have caused heavy degradation of many coastal habitats (Lotze et al., 2006), angling remains an important component of culture, economy, and recreation for many communities near estuaries. In this study, we were able to quantify the effects of various angling practices on fat snook in the Brazilian recreational fishery. Although there was a marked increase in physiological stress associated with all angling and tournament practices, we found that fat snook had high survival. Therefore, fat snook appear to be resilient to recreational fisheries capture given short angling durations and brief air exposure. However, we nonetheless suggest reducing air exposure intervals of snook during catch-and-release fishing and live-release angling tournaments in order to reduce physiological stress and maximize survival. Findings about the effects of recreational angling and tournament angling on snook provides a foundation for further research about the general ecology and behavior of the species in order to improve fishery management. This may in turn contribute to regulation of the fat snook fishery, which had not previously been addressed by management agencies due to a lack of biological data (Barcellini et al., 2013). In addition to addressing local beliefs that sport fisheries within the region are responsible for changes in fish abundance and species richness (Hanazaki et al., 2007), it will be important to manage conflicts that may arise as a result of spatial overlap between traditionally artisanal or commercial fishing sites and recreational fishers (Blaber et al., 2000).

\section{Acknowledgments}

We greatly appreciate the field support of Vilmar A Rodrigues, Gabriel R Souza, Cleber MR Imanobu, and João HC Mialich and thank the Instituto Chico Mendes de Conservação da Biodiversidade (ICMBio) for the research authorization (SISBIO $\mathrm{n}^{\circ}$ 44554-1). DGN had financial support from PROPe/UNESP (grant \#0360/001/14); RJL, JWB, and SJC are supported by the Natural Sciences and Engineering Research Council of Canada (NSERC). SJC is additionally supported by the Canada Research Chairs Program and Carleton University. AJD is supported by the National Institute of Food \& Agriculture, U.S. Department of Agriculture, and the Massachusetts Agricultural Experiment Station.

\section{References}

Alós, J., 2009. Mortality impact of recreational angling techniques and hook types on Trachynotus ovatus (Linnaeus, 1758) following catch-and-release. Fish. Res. 95, 365-369.

Alós, J., Cerdà, M., Deudero, S., Grau, A.M., 2008. Influence of hook size and type on short-term mortality, hooking location and size selectivity in a Spanish recreational fishery. J. Appl. Ichthyol. 24, 658-663.

Alvarez-Lajonchère, L., Tsuzuki, M.Y., 2008. A review of methods for Centropomus spp. (snooks) aquaculture and recommendations for the establishment of their culture in Latin America. Aquac. Res. 39, 684-700.

Arlinghaus, R., Cooke, S.J., 2009. Recreational fisheries: socioeconomic importance conservation issues and management challenges. In: Dickson, B., Hutton, J., Adams, W.A. (Eds.), Recreational Hunting, Conservation and Rural Livelihoods: Science and Practice. Blackwell Science, Oxford, pp. 39-58.

Arlinghaus, R., Cooke, S.J., Lyman, J., Policansky, D., Schwab, A., Suski, C., Sutton, S.G., Thorstad, E.B., 2007. Understanding the complexity of catch-and-release in recreational fishing: an integrative synthesis of global knowledge from historical, ethical, social, and biological perspectives. Rev. Fish. Sci. 15, 75-167.

Barcellini, V.C., Motta, F.S., Martins, A.M., Moro, P.S., 2013. Recreational anglers and fishing guides from an estuarine protected area in southeastern Brazil: socioeconomic characteristics and views on fisheries management. Ocean Coast. Manag. 76, 23-29.

Barella, W., Martins, A.G., Petrere, M., Ramires, M., 2014. Fishes of the southeastern Brazil atlantic forest. Environ. Biol. Fishes 97, 1-10.

Barthel, B.L., Cooke, S.J., Suski, C.D., Philipp, D.P., 2003. Effects of landing net mesh type on injury and mortality in a freshwater recreational fishery. Fish. Res. 63, $275-282$.

Bartholomew, A., Bohnsack, J.A., 2005. A review of catch-and-release angling mortality with implications for no-take reserves. Rev. Fish Biol. Fish. 15, 129-154.

Barton, B.A., 2002. Stress in fishes: a diversity of responses with particular reference to changes in circulating corticosteroids. Integr. Comp. Biol. 42, 517-525.

Blaber, S.J.M., Cyrus, D.P., Albaret, J.J., Ching, C.V., Day, J.W., Elliott, M., Fonseca, M.S., Hoss, D.E., Orensanz, J., Potter, I.C., Silvert, W., 2000. Effects of fishing on the structure and functioning of estuarine and nearshore ecosystems. ICES J. Mar. Sci. 57, 590-602.

Brownscombe, J.W., Thiem, J.D., Hatry, C., Cull, F., Haak, C.R., Danylchuk, A.J. Cooke, S.J., 2013. Recovery bags reduce post-release impairments in locomotory activity and behavior of bonefish (Albula spp.) following exposure to anglingrelated stressors. J. Exp. Mar. Biol. Ecol. 440, 207-215.

Brownscombe, J.W., Nowell, L., Samson, E., Danylchuk, A.J., Cooke, S.J., 2014. Fishingrelated stressors inhibit refuge-seeking behavior in released subadult great barracuda. Trans. Am. Fish. Soc. 143, 613-617.

Bunt, C.M., Cooke, S.J., Philipp, D.P., 2002. Mobility of riverine smallmouth bass related to tournament displacement and seasonal movements. Am. Fish. Soc Symp. 31, 356-363.

Contente, R.F., Stefanoni, M.F., Spach, H.L., 2011. Fish assemblage structure in an estuary of the Atlantic Forest biodiversity hotspot (southern Brazil). Ichthyol. Res. 58, 38-50.

Cooke, S.J., Schramm, H.L., 2007. Catch-and-release science and its application to conservation and management of recreational fisheries. Fish. Manag. Ecol. 14 73-79.

Cooke, S.J., Suski, C.D., 2005. Do we need species-specific guidelines for catch-andrelease recreational angling to effectively conserve diverse fishery resources? Biodivers. Conserv. 14, 1195-1209.

Cooke, S.J., Philipp, D.P., Schreer, J.F., McKinley, R.S., 2000. Locomotory impairment of nesting male largemouth bass following catch-and-release angling. North Am. J. Fish. Manag. 20, 968-977.

Cooke, S.J., Donaldson, M.R., O'Connor, C.M. Raby, G.D., Arlinghaus, R, Danylchuk, A.J., Hanson, K.C., Hinch, S.G., Clark, T.D., Patterson, D.A., Suski, C.D. 2013. The physiological consequences of catch-and-release angling: perspectives on experimental design, interpretation, extrapolation and relevance to stakeholders. Fish. Manag. Ecol. 20, 268-287.

Cooke, S.J., Messmer, V., Tobin, A.J., Pratchett, M.S., Clark, T.D., 2014. Refuge-seeking impairments mirror metabolic recovery following fisheries- related stressors in the Spanish flag Snapper (Lutjanus carponotatus) on the great barrier reef. Physiol. Biochem. Zool. 87, 136-147.

Danylchuk, S.E., Danylchuk, A.J., Cooke, S.J., Goldberg, T.L., Koppelman, J., Philipp, D.P., 2007. Effects of recreational angling on the post-release behavior and predation of bonefish (Albula vulpes): the role of equilibrium status at the time of release. J. Exp. Mar. Biol. Ecol. 346 (1), 127-133.

Davis, M.W., 2005. Behaviour impairment in captured and released sablefish: ecological consequences and possible substitute measures for delayed discard mortality. J. Fish Biol. 66, 254-265.

Davis, M.W., 2007. Simulated fishing experiments for predicting delayed mortality rates using reflex impairment in restrained fish. ICES J. Mar. Sci. 64, 1535-1542.

Davis, M.W., 2010. Fish stress and mortality can be predicted using reflex impairment. Fish Fish. 11, 1-11.

Davis, M.W., Ottmar, M.L., 2006. Wounding and reflex impairment may be predictors for mortality in discarded or escaped fish. Fish. Res, 82, 1-6.

Diegues, A.C.S., 1983. Pescadores, camponeses e trabalhadores do mar. São Paulo: Ática. (In Portuguese).

Dobson, G.P., Hochachka, P.W., 1987. Role of glycolysis in adenylate depletion and 
repletion during work and recovery in teleost white muscle. J. Exp. Biol. 129, $125-140$.

Dyck, A.J., Sumaila, U.R., 2010. Economic impact of ocean fish populations in the global fishery. J. Bioeconomics 12, 227-243.

FAO, 2000. The State of World Fisheries and Aquaculture. Food and Agriculture Organisation of the United Nations, Rome.

Ferguson, R.A., Tufts, B.L., 1992. Physiological effects of brief air exposure in exhaustively exercised rainbow trout (Oncorhynchus mykiss): implications for "catch and release" fisheries. Can. J. Fish. Aquat. Sci. 49, 1157-1162.

Freire, K.M., Machado, M.L., Crepaldi, D., 2012. Overview of inland recreational fisheries in Brazil. Fisheries 37, 484-494.

Gingerich, A.J., Cooke, S.J., Hanson, K.C., Donaldson, M.R., Hasler, C.T., Suski, C.D., Arlinghaus, R., 2007. Evaluation of the interactive effects of air exposure duration and water temperature on the condition and survival of angled and released fish. Fish. Res. 86, 169-178.

Hanazaki, N., Castro, F.D., Oliveira, V.G., Peroni, N., 2007. Between the sea and the land: the livelihood of estuarine people in southeastern Brazil. Ambiente Soc. $10,121-136$.

Harden Jones, F.R., 1994. Fisheries Ecologically Sustainable Development: Terms and Concepts. IASOS. University of Tasmania, Hobart, Australia.

Humborstad, O.B., Davis, M.W., Løkkeborg, S., 2009. Reflex impairment as a measure of vitality and survival potential of Atlantic cod (Gadus morhua). Fish. Bull. 107, $395-402$.

Kieffer, J.D., 2000. Limits to exhaustive exercise in fish. Comp. Biochem. Physiol. Part A $126,161-179$.

Lana, P.C., Marone, E., Lopes, R.M., Machado, E.C., 2001. The subtropical estuarine complex of Paranaguá Bay, Brazil. In: Coastal Marine Ecosystems of Latin America. Springer Berlin Heidelberg, pp. 131-145.

Lemos, D., Netto, B., Germano, A., 2006. Energy budget of juvenile fat snook Centropomus parallelus fed live food. Comp. Biochem. Physiol. Part A Mol. Integr. Physiol. 144, 33-40.

Lennox, R., Whoriskey, K., Crossin, G.T., Cooke, S.J., 2015. Influence of angler hookset behaviour relative to hook type on capture success and incidences of deep hooking and injury in a teleost fish. Fish. Res. 164, 201-205.

Lino, C.F., Moraes, M.B., 2005. Protecting landscapes and sea coastal regions of Brazil. In: Brown, J., Mitchell, N. (Eds.), The Protected Landscape Approach: Linking Nature. IUCN - World Commission on Protected Areas, England.

Lotze, H.K., Lenihan, H.S., Bourque, B.J., Bradbury, R.H., Cooke, R.G., Kay, M.C., Kidwell, S.M., Kirby, M.X., Peterson, C.H., Jackson, J.B., 2006. Depletion, degradation, and recovery potential of estuaries and coastal seas. Science 312, 1806-1809.

Lowerre-Barbieri, S.K., Vose, F.E., Whittington, J.A., 2003. Catch-and-release fishing on a spawning aggregation of common snook: does it affect reproductive output? Trans. Am. Fish. Soc. 132, 940-952.

Mazeaud, M.M., Mazeaud, F., Donaldson, E.M., 1977. Primary and secondary effects of stress in fish: some new data with a general review. Trans. Am. Fish. Soc. 106, $201-212$.

Milligan, C.L., Wood, C.M., 1986. Tissue intracellular acid-base status and the fate of lactate after exhaustive exercise in the rainbow trout. J. Exp. Biol. 123, 123-144.

Mommsen, T.P., Vijayan, M.M., Moon, T.W., 1999. Cortisol in teleosts: dynamics, mechanisms of action, and metabolic regulation. Rev. Fish Biol. Fish. 9, 211-268.

Moro, P.S., 2008. Prospecção do estoque de robalo-peva (Centropomus parallelus) no litoral do Paraná, através da pesca esportiva. Dissertação. Universidade Federal do Ceará (Programa de Pós-Graduação em Engenharia de Pesca), Fortaleza. unpublished. (In Portuguese).

Moro, P.S., Mendonça, J.T., Motta, F.S., 2010. Diagnóstico e caracterização da pesca amadora no Complexo Estuarino-Lagunar de Iguape, Cananéia e Ilha Comprida, litoral sul do Estado de São Paulo. São Paulo: Conservação Internacional unpublished. (In Portuguese).

Mourão, F.A.A., 1971. Os pescadores do Litoral Sul do Estado de São Paulo: um estudo de sociologia diferencial. Doctoral Thesis, Universidade de São Paulo, Sao Paolo unpublished. (In Portuguese).

Muoneke, M.I., Childress, W.M., 1994. Hooking mortality: a review for recreational fisheries. Rev. Fish. Sci. 2, 123-156.

Pankhurst, N.W., 2011. The endocrinology of stress in fish: an environmental perspective. General Comp. Endocrinol. 170, 265-275.

Pelletier, C., Hanson, K.C., Cooke, S.J., 2007. Do catch-and-release guidelines from state and provincial fisheries agencies in North America conform to scientifically based best practices? Environ. Manag. 39, 760-773.

Post, J.R., Sullivan, M., Cox, S., Lester, N.P., Walters, C.J., Parkinson, E.A., Paul, A.J., Jackson, L., Shuter, B.J., 2002. Canada's recreational fisheries: the invisible collapse? Fisheries 27, 6-17.

Pottinger, T.G., 1998. Changes in blood cortisol, glucose and lactate in carp retained in anglers' keepnets. J. Fish Biol. 53, 728-742.

R Core Team, 2014. R: a Language and Environment for Statistical Computing. R Foundation for Statistical Computing, Vienna, Austria. ISBN 3-900051-07-0, URLhttp://www.R-project.org.

Raby, G.D., Donaldson, M.R., Hinch, S.G., Patterson, D.A., Lotto, A.G., Robichaud, D., English, K.K., Willmore, W.G., Farrell, A.P., Davis, M.W., Cooke, S.J., 2012. Validation of reflex indicators for measuring vitality and predicting the delayed mortality of wild coho salmon bycatch released from fishing gears. J. Appl. Ecol. 49, 90-98.

Raby, G.D., Packer, J.R., Danylchuk, A.J., Cooke, S.J., 2014. The understudied and underappreciated role of predation in the mortality of fish released from fishing gears. Fish Fish. 15, 489-505. http://dx.doi.org/10.1111/faf.12033.

Rawlinson, N.J.F., Milton, D.A., Blaber, S.J.M., Sesewa, A., Sharma, S., 1995. The subsistence fishery of Fiji. ACIAR Monogr. 35, 1-138.

Schramm Jr., H.L., Armstrong, M.L., Funicelli, N.A., Green, D.M., Lee, D.P., Manns Jr., R.E., Taubert, B.D., Waters, S.J., 1991. The status of competitive sport fishing in North America. Fisheries 16, 4-12.

Siewert, H.F., Cave, J.B., 1990. Survival of released bluegill, Lepomis macrochirus, caught on artificial flies, worms, and spinner lures. J. Freshw. Ecol. 5, 407-411.

Stoot, L.J., Cairns, N.A., Cull, F., Taylor, J.J., Jeffrey, J.D., Morin, F., Mandelman, J.W., Clark, T.D., Cooke, S.J., 2014. Use of portable blood physiology point-of-care devices for basic and applied research on vertebrates - a review. Conserv. Physiol. http://dx.doi.org/10.1093/conphys/cou011.

Suski, C.D., Killen, S.S., Cooke, S.J., Kieffer, J.D., Philipp, D.P., Tufts, B.L., 2004. Physiological significance of the weigh-in during live-release angling tournaments for largemouth bass. Trans. Am. Fish. Soc. 133, 1291-1303.

Suski, C.D., Cooke, S.J., Danylchuk, A.J., O'Connor, C.M., Gravel, M.A., Redpath, T., Hanson, K.C., Gingerich, A.J., Murchie, K.J., Danylchuk, S.E., Koppelman, J.B., Goldberg, T.L., 2007. Physiological disturbance and recovery dynamics of bonefish (Albula vulpes), a tropical marine fish, in response to variable exercise and exposure to air. Comp. Biochem. Physiol. Part A Mol. Integr. Physiol. 148, $664-673$.

Taylor, R.G., Whittington, J.A., Haymans, D.E., 2001. Catch-and-release mortality rates of common snook in Florida. North Am. J. Fish. Manag. 21, 70-75.

Thomas, P., 1990. Molecular and biochemical responses of fish to stressors and their potential use in environmental monitoring. Am. Fish. Soc. Symp. 8, 9-28.

Thompson, L.A., Cooke, S.J., Donaldson, M.R., Hanson, K.C., Gingerich, A., Klefoth, T., Arlinghaus, R., 2008. Physiology, behavior, and survival of angled and airexposed largemouth bass. North Am. J. Fish. Manag. 28, 1059-1068.

van Raaij, M.T., Pit, D.S., Balm, P.H., Steffens, A.B., van den Thillart, G.E., 1996. Behavioral strategy and the physiological stress response in rainbow trout exposed to severe hypoxia. Hormones Behav. 30, 85-92.

Wedemeyer, G.A., Wydoski, R.S., 2008. Physiological response of some economically important freshwater salmonids to catch-and-release fishing. North Am. J. Fish. Manag. 28, 1587-1596.

Wendelaar Bonga, S., 1997. The stress response in fish. Physiol. Rev. 77, 591-625.

White, A.J., Schreer, J.F., Cooke, S.J., 2008. Behavioral and physiological responses of the congeneric largemouth (Micropterus salmoides) and smallmouth bass (M. dolomieu) to various exercise and air exposure durations. Fish. Res. 89, 9-16.

Wilde, G.R., 2003. Dispersal of tournament-caught black bass. Fisheries 28, 10-17.

Wilde, G.R., Pope, K.L., Durham, B.W., 2003. Lure-size restrictions in recreational fisheries. Fisheries 28, 18-26.

Wood, C.M., 1991. Acid-base and ion balance, metabolism, and their interactions, after exhaustive exercise in fish. J. Exp. Biol. 160, 285-308.

Wood, C.M., Turner, J.D., Graham, M.S., 1983. Why do fish die after severe exercise? J. Fish Biol. 22, 189-201. 